Ind. Health, 1967, 5, 149.

\title{
PLACENTAL TRANSFER OF MERCURIC CHLORIDE, PHENYL MERCURY ACETATE AND METHYL MERCURY ACETATE IN MICE
}

\author{
Tsuguyoshi SUZUKI, Nobuo MATSUMOTO, Tomoyo MIYAMA \\ and Haruo KATSUNUMA
}

Department of Public Health, Faculty of Medicine, University of Tokyo, Hongo, Bunkyo-ku, Tokyo

(Received February 15, 1967)

\begin{abstract}
Three mercury compounds, such as mercuric chloride, phenyl mercury acetate and methyl mercury acetate, are subcutaneously injected to pregnant mice at the 14th day of their gestation. By use of radioactive mercury $\left({ }^{203} \mathrm{Hg}\right)$, the extents of placental transfer are estimated on each mercury compound. The mercury of methyl mercury acetate is the most transferable across the placenta and the mercury of mercuric chloride and phenyl mercury acetate is blocked to about the same degree. The retention of mercury in the amniotic membrane also differs with the sort of mercury compounds; the largest amount of mercury is found in the case of mercuric chloride and the smallest is in the case of methyl mercury chloride.
\end{abstract}

In these several years, it has been well recognized that there are differences on the distribution and excretion of mercury compounds, which have different chemical structures.1 11) For instance, mercury of methyl and ethy! mercury compounds is very slowly excreted and has a comparatively high affinity to the central nervous system, but mercury of inorganic mercury compounds is excreted fastly and has a dominant affinity to the kidney.

On the placental transfer of mercury compounds,18,19) however, no systematic research has been reported, though Berlin and U11berg $\left.{ }^{12} 14\right)$ made some observation on it. They compared the accumulation and retention of mercuric chloride, phenyl mercury acetate and methyl mercury dicyandiamide in mice by the autoradiographic technique, and some of the female mice they used were pregnant. On which day of pregnancy mercury compounds were injected were not described in their reports. They observed that the placenta seemed to act as a barrier to mercury of mercuric chloride and of phenyl mercury acetate, but not to mercury of methyl mercury dicyandiamide. It was worthwhile to note that the yolk sac epithelium and the fetal membrane had higher retentions of mercury than the placenta in case of phenyl mercury acetate injection. They also described that the darkening in the autoradiogram was only slight on the visceral yolk sac epithelium of mice injected with mercuric 


\section{T. SUZUKI, N. MATSUMOTO, T. MIYAMA AND H. KATSUNUMA}

chloride, but no description was seen for the retention of mercury on the yolk sac epithelium of mice injected with methyl mercury dicyandiamide.

Drugs with less degrees of dissociation and/or high lipid solubilities are known to penetrate the placenta easily and reach at the equilibrium between maternal blood and fetal blood.15,16) Among mercury compounds, alkyl mercury salts have high lipid solubilities and are less dissociable at physiologic $\mathrm{pH}$ ranges. Then the observation that the placenta did not act as a barrier to mercury of methyl mercury salt, is most probable, but the high retention of mercury of mercuric chloride and phenyl mercury acetate in the yolk sac epithelium and fetal membrane is unexpected and not explainable by the informations in the literature.

The present investigation aimed to verify the observation by Berlin and Ullberg with the experiment, in which th administration of mercury compounds was carried out on the fixed date of gestation period.

\section{Materials and Methods}

Experimental animals. Nineteen adult nulliparous female mice, ddD strain, were divided into two groups. The first group, comprising $10 \mathrm{mice}$, was used to test placental transfer of mercury compounds, and the second group was used as non-pregnant control. The mice of first group were mated individually, and the day when vaginal plug was found, was decided to be the zero day of gestation period.

The mice were maintained with a commercial chow, purchased from Nihon Clea Co. Their body weights ranged from 26 to 29 grams.

Radioactive mercury compounds. Radioactive mercuric chloride was purchased from the Radiochemical Center and radioactive phenyl and methyl mercury $\left(\mathrm{Hg}^{203}\right)$ acetates were prepared by the method previously reported.10)

Administration of mercury compounds. At the 14th day of the gestation period, mercury compounds were injected subcutaneously. Injected dose of each compound was as follows: mercuric chloride; $1.5 \mathrm{mg}$ of $\mathrm{Hg} / 21 \mu \mathrm{C} / \mathrm{kg}$, phenyl mercury acetate; $2.5 \mathrm{mg}$ of $\mathrm{Hg} / 20 \mu \mathrm{C} / \mathrm{kg}$ and methyl mercury acetate; $2.5 \mathrm{mg}$ of $\mathrm{Hg} / 20 \mu \mathrm{C} / \mathrm{kg}$.

Harvesting of organs and fetuses. At the 18th day of the gestation period, namely 4 days after injection, the animals were killed by heart puncture and the placentas, amniotic membranes, amniotic fluids, livers, kidneys and uteri were harvested. The uterus, in which fetuses were held was removed at first as a whole. The muscle of uterus were carefully separated from the maternal side of placenta. Then, the placenta, amniotic membrane and fetus were harvested separatively. The amniotic fluid, which filled amniotic cavity, was blotted with a filter paper. 


\section{PLACENTAL TRANSFER OF MERCURY COMPOUNDS}

Estimation of radioactivities. Radioactivities in the tissues and organs were estimated with a well-type scintillation counter.

Comparison of the distribution pattern of mercury between pregnant and non-pregnant mice. Non-pregnant mice were injected with the same dose of each mercury compound when pregnant mice were injected. The liver, kidney, uterus and blood were harvested 4 days after injection and the content of mercury in each organ was compared with that obtained on pregnant mice.

\section{Results}

\section{Transfer of mercury to the fetus}

Amounts and concentrations of mercury in the individual fetuses are shown in Table 1. Among three groups, the transferred amount of mercury is the largest in methyl mercury acetate (MMA) group. The smallest transfer is observed on phenyl mercury acetate (PMA) group. The transferred mercury of mercuric chloride (MC) is about double the amount of that of PMA and one tenth the amount of that of MMA.

Table 1. Transfer of mercury to individual fetus.

\begin{tabular}{|c|c|c|c|c|c|c|}
\hline \multicolumn{2}{|c|}{$\begin{array}{l}\text { No. of litter } \\
\text { Compound }\end{array}$} & $\stackrel{1}{\text { Mean(range) }}$ & $\stackrel{2}{2}$ Mean(range) & $\stackrel{3}{\text { Mean(range) }} 1$ & $\stackrel{4}{\text { Mean(range) }}$ & $\begin{array}{c}\text { Total } \\
\text { Mean(S.D. }\end{array}$ \\
\hline$M$ & Size of litter & 5 & 2 & 4 & & \\
\hline $\mathrm{C}$ & $\begin{array}{l}\% \text { of transferred } \\
\text { amount of } \mathrm{Hg} \\
\text { concentration of } \\
\mathrm{Hg}(\mathrm{cpm} / \mathrm{g})\end{array}$ & $\begin{array}{l}0.129 \\
(0.120-0.150) \\
602 \\
(576-634)\end{array}$ & $\begin{array}{l}0.178 \\
(0.148-0.208) \\
676 \\
(662-691)\end{array}$ & $\begin{array}{l}0.144 \\
(0.124-0.162) \\
605 \\
(514-698)\end{array}$ & & $\begin{array}{l}0.143 \\
(0.026) \\
617 \\
(67)\end{array}$ \\
\hline$M$ & Size of litter & 4 & 3 & 6 & 5 & \\
\hline A & $\begin{array}{l}\% \text { of transferred } \\
\text { amount of Hg } \\
\text { concentration of } \\
\mathrm{Hg}(\mathrm{cpm} / \mathrm{g})\end{array}$ & $\begin{array}{l}1.78 \\
(1.56-2.25) \\
7306 \\
(6632-7858)\end{array}$ & $\begin{array}{l}1.55 \\
(1.37-1.66) \\
6537 \\
(6413-6722)\end{array}$ & $\begin{array}{l}1.16 \\
(1.00-1.29) \\
5485 \\
(5062-5896)\end{array}$ & $\begin{array}{l}1.24 \\
(0.98-1.45) \\
5741 \\
(5470-5866)\end{array}$ & $\begin{array}{l}1.39 \\
(0.317) \\
6137 \\
(793)\end{array}$ \\
\hline & Size of litter & 6 & 8 & 4 & & \\
\hline $\begin{array}{l}\mathrm{M} \\
\mathrm{A}\end{array}$ & $\begin{array}{l}\% \text { of transferred } \\
\text { amount of } \mathrm{Hg} \\
\text { concentration of } \\
\mathrm{Hg}(\mathrm{cpm} / \mathrm{g})\end{array}$ & $\begin{array}{l}0.085 \\
(0.070-0.096) \\
385 \\
(332-510)\end{array}$ & $\begin{array}{l}0.063 \\
(0.046-0.084) \\
305 \\
(241-258)\end{array}$ & $\begin{array}{l}0.080 \\
(0.075-0.083) \\
328 \\
(307-340)\end{array}$ & & $\begin{array}{l}0.074 \\
(0.014) \\
337 \\
(56)\end{array}$ \\
\hline
\end{tabular}

Note. The numerals presented as concentration are not original data but corrected on the assumption that the radioactivities administered are same irrespective to the sort of mercury compounds.

MC: mercuric chloride, MMA: methyl mercury acetate, PMA: phenyl mercury acetate, and S. D.: standard deviation.

In all three groups, every fetus inherent in a specific litter has an almost equal amount of mercury. Therefore, the total amount of mercury transferred to a litter is proportional to the number of fetuses presented in the litter. Litter to litter variation of transfer of mercury is slight on the standpoint of transfer of specific mercury compound to an individual fetus. 


\section{T. SUZUKI, N. MATSUMOTO, T. MIYAMA AND H. KATSUNUMA}

Distribution of mercury in the fetus and its appendage

Distribution of mercury in the fetus, divided into the head and other part, placenta and amniotic membrane, is shown in Figs. 1 and 2. As for the concentration of mercury, MMA has distributed uniformly in the two parts of fetus and placenta, but less in the amniotic membrane. MC and PMA, especially the former, have distinctively higher retentions on the amniotic membrane and placenta than on the fetus, in which no difference is found in the concentration of mercury. Comparing the retained amount of mercury among three mercury compounds, no further difference is obtained.

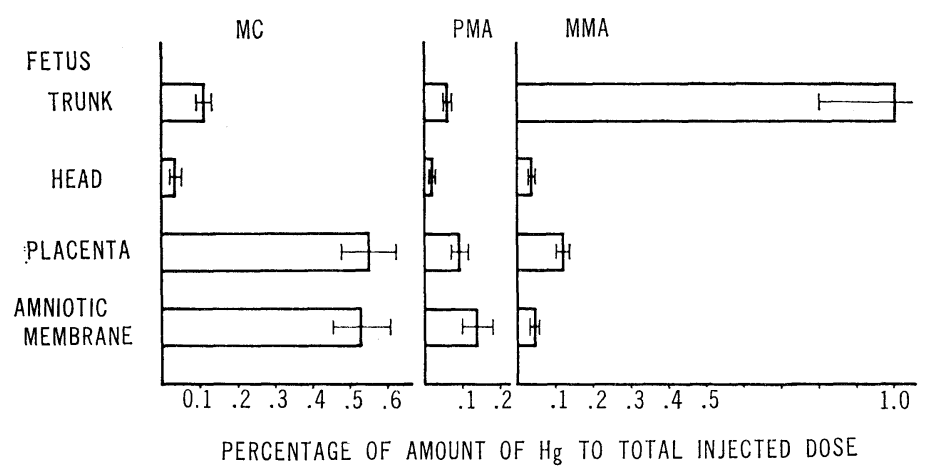

Fig. 1. Distribution of mercury in the fetus and its appendage-1. MC : Mercuric Chloride, PMA: Phenyl Mercury Acetate, MMA: Methyl Mercury Acetate Each column shows mean and standard deviation.

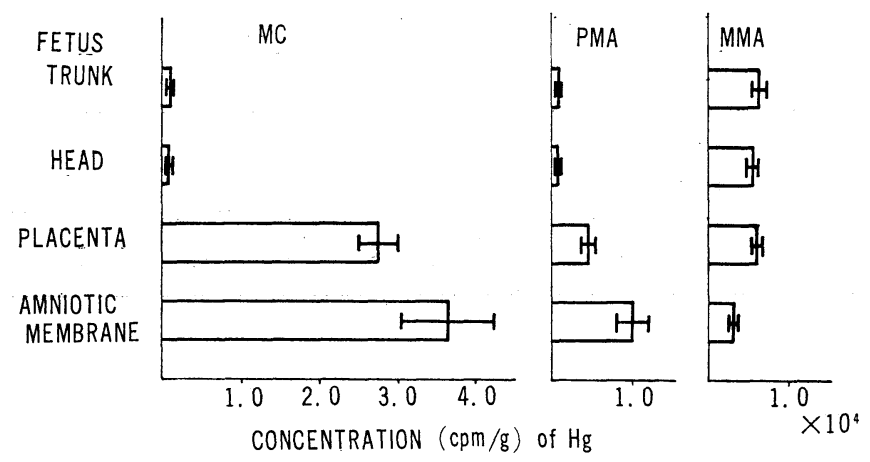

Fig. 2. Distribution of mercury in the fetus and its appendage-2.

The placenta seemed to act as a barrier to mercury of MC and PMA, though not to mercury of MMA. The concentration and amount of mercury in the amniotic membrane are the most interesting finding. $\mathrm{MC}$ is the highest and largest, and MMA is the lowest and smallest. What does this finding mean?

The concentrations of mercury in the amniotic fluid are shown in Table 2. There are somewhat large fluctuations in the data, which seem to be due to the technical difficulty in preparing samples for radioactivity estimation. Mean values of the concentration do not differ so large among three mercury 


\section{PLACENTAL TRANSFER OF MERCURY COMPOUNDS}

compounds.

Table 2. Concentration of mercury in the Amniotic fluid.

\begin{tabular}{|c|c|c|c|c|c|}
\hline $\begin{array}{l}\text { No. of litter } \\
\text { compound }\end{array}$ & 1 & 2 & 3 & 4 & Mean \\
\hline $\begin{array}{l}\text { Mercuric chloride } \\
\qquad(\mathrm{cpm} / \mathrm{g})\end{array}$ & $89, \quad 333$ & $785, \quad 1091$ & 364 & & 584 \\
\hline $\begin{array}{l}\text { Methyl mercury } \\
\text { acetate }(\mathrm{cpm} / \mathrm{g})\end{array}$ & 926 & 489 & 378 & $451, \quad 402$ & 577 \\
\hline $\begin{array}{l}\text { Phenyl mercury } \\
\text { acetate }(\mathrm{cpm} / \mathrm{g})\end{array}$ & $596, \quad 250$ & 712 & 404 & & 501 \\
\hline
\end{tabular}

Comparison of distribution of mercury in some organs between pregnant and nonpregnant mice

Results are shown in Table 3. Reflecting the increase of weight of uterus in pregnant animal, the amounts of mercury in the pregnant uteri are larger than those in the non-pregnant uteri in all three groups. But, only in the case of $\mathrm{MC}$, the concentration of mercury in the pregnant uterus is higher than that in the non-pregnant uterus. The kidneys of pregnant mice have also higher content of mercury only in the case of MC.

Table 3. Comparison of mercury distribution between pregnant and non-pregnant mice.

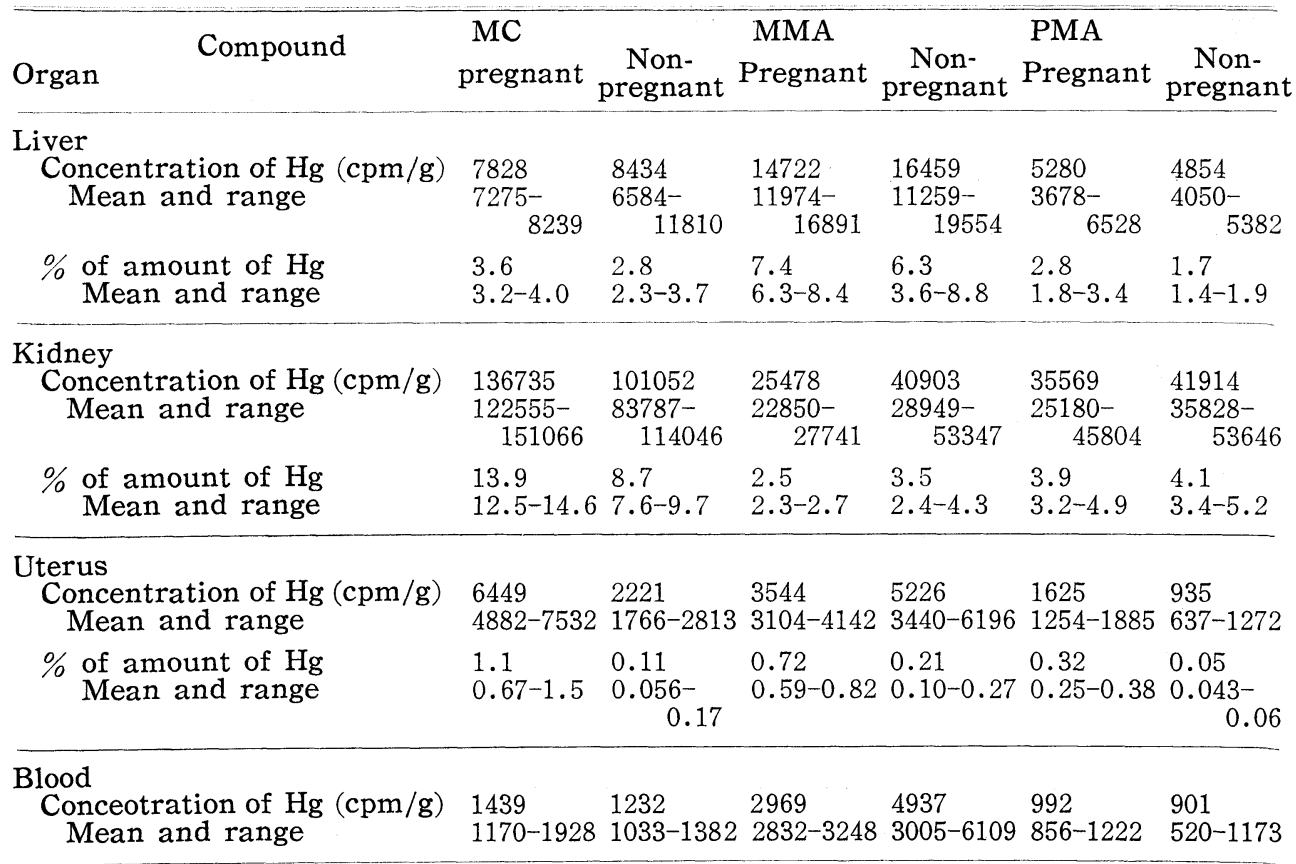




\section{T. SUZTKI, N. MATSUMOTO, T. MIYAMA AND H. KATSUNUMA \\ Discussion}

As far as the present data concern, the placental transfer of mercury certainly changes with the chemical nature of mercury compounds as already mentioned by Berlin and Ullberg.12-14) The ratios of mercury concentrations in the maternal blood, placenta and fetus, are $1: 19: 0.4$ in the case of MC, $1: 1.9: 2.1$ in the case of MMA and $1: 4.5: 0.3$ in the case of PMA. The extent of blocking the passage of mercury to the fetus in $\mathrm{MC}$ is similar to that in PMA, but the mercury of MMA seems to pass freely by the placenta. In the placenta itself, there seems to be some differences in binding and releasing of mercury according to the chemical nature of mercury compounds.

On the retention of mercury in the amniotic membrane, water solubility of mercury compound seems to play an important role to determine the extent of retention. The higher the water solubility of mercury compound is, the more the amount of mercury in the amniotic membrane is. With the transport of water from the amniotic fluid to the fetus and from the fetus to the amniotic fluid, mercury might move and be retained on the amniotic membrane.

In mice, the yolk sac is known to persist and act as an absorption organ up to the considerably late stage of gestation, but the present authors can not obtain any information on retention of mercury in the yolk sac epithelium. Whether or not, the mechanisms of retention of mercury to the amniotic membrane and to the epithelium of yolk sac are the same, can not be discussed here.

\section{ACKNOWLEDGEMENT}

The present authors wish to express cordial thanks to Mr. Jitsu, Hokuko Chemicals Co., for his help in preparation of radioactive mercury compounds.

\section{REFERENCE}

1) Friberg, L., Odeblad, E. and Forssman, S. (1957). A. M. A. Arch. Ind. Health, 16, 163.

2) Friberg, L. (1959). A. M. A. Arch. Ind. Health, 20, 42.

3) Swensson, A., Lundgren, K-D. and Lindström, O. (1959). A. M. A. Arch. Ind. Health, 20, 432 .

4) Swensson, A., Lundgren, K-D. and Lindström, O. (1959). A. M. A. Arch. Ind. Health, 20, 467.

5) Miller, V. L., Klavano, P. A. and Csonka, E. (1960). Toxicol. Appl. Pharmacol., 2, 344.

6) Miller, V. L., Klavano, P. A., Jerstad, A. C. and Csonka, E. (1961). Toxicol. Appl. Pharmacol., 3, 459.

7) Gage, J. C., and Swan, A. A. B. (1961). Biochem. Pharmacol., 8, 77.

8) Prickett, C. A., Laug, E. P. and Kunze, F. M. (1950). Proc. Soc. Exptl. Biol. Med., 73, 585.

9) Berlin, M. (1963). Acta Med. Scand., Suppl. 396. 


\section{PLACENTAL TRANSFER OF MERCURY COMPOUNDS}

10) Katsunuma, H., Suzuki, T. and Miyama, T. (1961). Japan. J. Med. Progress, 48, 373. (in Japanease)

11) Suzuki, T., Miyama, T. and Katsunuma, H. (1961). Japan. J. Med. Progress, 48, 716. (in Japanese)

12) Berlin, M. and Ullberg, S. (1963). A. M. A. Arch. Environ. Health, 6, 589.

13) Berlin, M. and Ullberg, S. (1963). A. M. A. Arch. Environ. Health, 6, 602.

14) Berlin, M. and Ullberg, S. (1963). A. M. A. Arch. Environ. Health, 6, 610.

15) Moya, F. and Thorndike, V. (1962). Am. J. Obstet. Gynecol., 84, 1778.

16) Villee, C. A. (1965). Ann. N. Y. Acad. Sci., 123, 237.

17) Sternberg, J. (1962) Am. J. Obstet. Gynecol., 84, 1731.

18) Morikawa, N. (1961). Kumamoto Med. J., 14, 71.

19) Kajitani, K. (1954). Japan. J. Hyg., 9, 76. (in Japanese) 